\title{
Fingerboard Media Development Calculate for the Cognitive Improvement of Teachers at RA Muslimat NU 1 Tulus Rejo
}

\author{
Dewi Maftutah \\ maftutahdwi21@gmail.com \\ Institut Agama Islam Ma'arif NU (IAIMNU) Metro Lampung \\ Siti Roudhotul Jannah \\ sitirioudhotuljannah44@gmail.com \\ Institut Agama Islam Ma'arif NU (IAIMNU) Metro Lampung \\ Ferdian Utama \\ ferdianutama@gmail.com \\ Institut Agama Islam Ma'arif NU (IAIMNU) Metro Lampung
}

\begin{abstract}
The development of media as a tool to improve children's development, especially at the early childhood education level, is very important. The assistance of media or educational play tools in children's activities at school is directly proportional to the slogan of playing while learning. This article aims to explain about letter board media assistance for PAUD teachers in schools, as well as children's cognitive enhancement through counting board media. The data used were obtained from observations, interviews, tests and interviews. This article finds that the development of finger pad media makes it easier for teachers as well as aids in children's cognitive enhancement. The finger board media used by the teacher has an impact on the joy of children with the media used. This article strengthens some of the previous articles about cognitive enhancement in children assisted by fun fingertip media.
\end{abstract}

Keywords: Fingerboard Media, Cognitive Improvement, RA Muslimat

(C) 2021 Dewi Maftutah, Siti Roudhotul Jannah, Ferdian Utama

\section{INTRODUCTION}

Early childhood has various abilities that need to be developed. Children's education is carried out to prepare them to be part of a useful society (M. Yusuf, Ani Susilawati, 2019). One of the efforts made is to improve cognitive through the use of media in the learning process. Media is part of the learning component, the benefits and functions of media in learning are greatly felt by both educators and students. The success of the media in improving student learning quality is determined by how the teacher's ability to choose the media to be used. (Mahnun, 2012) Therefore, this study will research and develop learning media in the form of counting finger boards in early childhood. 
The counting board media was developed with the aim that mathematics subjects, especially in the distribution material which is sometimes considered difficult by students, will be more fun, so that in their learning activities students will not feel bored quickly, besides that it is also expected that this media can help students speed in the counting process. Because mathematics is one of the sciences that must be studied at every level of education. Mathematical objects are abstract. Many students are not happy and passionate about learning mathematics, because it is abstract. (Suharmanto, 2014)

Based on pre-survey data, the use of counting finger pad at RA Muslimat NU 1 Tulus Rejo Kec. Pekalongan Kab. East Lampung has not been implemented, therefore the authors are interested in conducting research using counting finger pad media. With the application of counting finger board media, children will enthusiastically participate in learning with new learning media, besides that, besides the easy way of making it, the materials needed in making the media are also classified as easy to obtain.

Early childhood is a golden age or often called the Golden Age. At this time the child's brain has experienced the fastest development in the history of his life. This occurs when the child is in the womb until an early age, namely the age of zero to six years. However, from the time of the baby in the womb to birth, until the age of four years is the most decisive period. This period, the child's brain is experiencing very rapid growth.(Fauziddin, 2018) Every child is born with different levels of intelligence and indicators.

Early childhood education is very important for further education. Early childhood education provides opportunities to develop children's personalities with various aspects of development. There are several aspects of development that must be developed in every learning process in early childhood education, one of which is the achievement of development in the cognitive field. Cognitive is a thinking process, namely the individual's ability to connect, assess, and consider an event or event. (Rohani, 2016)

The goal of cognitive development is directed in various fields, one of which is arithmetic. Arithmetic development is a development aimed at mastery of preliminary arithmetic or the concept of preliminary arithmetic. The ability to count early is an ability that is owned by every child to develop their abilities. Characteristics of development starting from the environment closest to him, the development of children's abilities can increase to the stage of understanding the amount that is related to addition and subtraction.

Islam gives a very high position in the form of mind and reason which only humans have, and humans are the best of Allah's creations. Allah commands man to use his mind and reason as well as possible. This saying is found in the Qur'anic surah An-Nahl ayat 11.




Artinya : "He causes to grow for you with it crops; olives, dates, grapes and all kinds of fruits. Lo! Herein verily is a portent for a people who give thought." (Qs. An-Nahl 16:11). (RI, 2009)

Based on the above verse, it is explained that (He grows for you with the water plants, olives, dates, grapes and all kinds of fruits. Verily in that) the thing that has been mentioned (really there is a sign) that shows the oneness of Allah Almighty. (For those who think) about His creation so that they will believe because of it.

In accordance with the Regulation of the Minister of Education and Culture Number 137 of 2014 concerning Standard Content of Child Development Achievement Levels cited by Noor Arinda Fauziah Rizky, it is stated that indicators of cognitive development of children aged 4-5 years are able to recognize the concept of numbers 1-10 and symbols of numbers 1-10.(Rizky, 2017)

But in reality early childhood at RA Muslimat NU 1 Tulus Rejo Kec. Pekalongan Kab. East Lampung, children are less able to develop cognitive abilities well. For that, we need to prepare children to be ready to learn well, diligently and correctly. In this regard, early childhood needs to be prepared to learn to develop cognitive, which is one of the indicators in the Basic Ability in the 2013 curriculum.

Increasing cognitive abilities in the aspect of symbolic thinking which is the subject of this study. The author chose cognitive abilities because of these cognitive abilities in RA Muslimat NU 1 Tulus Rejo Kec. Pekalongan Kab. East Lampung is still relatively low, as evidenced by the results of a pre-survey of cognitive intelligence of children aged 4-5 years.

Based on the description of the background above, this study chose the title "Media Development of Counting Finger Boards in Improving Cognitive Intelligence (Logical Thinking) of Children aged 4. -5 Years at RA Muslimat NU 1 Tulus Rejo Kec. Pekalongan Kab. East Lampung Academic Year 2020/2021 ".

\section{METHODOLOGY}

This research is in the form of R\&D which is taken from the development of Brog and Gell (Gall, 2003), the subject of this research is RA 1 Muslimat Tulus Rejo, East Lampung, which is analyzed using the guidelines for the assessment criteria to determine the quality of the developed Counterboard media.

\section{RESULTS AND DISCUSSION}

\section{Potential and Problems Potensi}

Potential is anything that, if utilized, will have added value. With the application of counting finger pad media, so that children will be enthusiastic about learning with new learning media, besides that in addition to the easy way of making it, the materials needed in making the media are also classified as easy to obtain.

\section{Problem}

Problem is a deviation between what is expected and what is happening. Based on pre-survey data, the cognitive abilities of children aged 4-5 years in RA Muslimat NU 1 Tulus Rejo Kec. Pekalongan Kab. East Lampung is still classified as underdeveloped, therefore researchers are interested in conducting research using counting finger boards to improve cognitive abilities. 


\section{Product Design}

This stage begins by compiling a product design in the form of counting finger board teaching materials for children aged 4-5 years. The making of teaching materials is done first by making a description of the material, and the learning design of the teaching materials. Counting finger board media or flannel board media is a flat board media covered by a flannel cloth on which pieces of letters, numbers, pictures and symbols can be placed to facilitate the learning process. This counting finger board media is generally used in low-grade Kindergarten or Elementary School learning. Counting finger pad media is often used in initial learning such as number recognition and addition concepts.

The following is the design of the counting finger board media product that researchers will develop, l.e :

Tabel 1.1

Calculated Finger Board Media Design

\begin{tabular}{|c|c|}
\hline Desain & Gambar \\
\hline Media Boards & \\
Finger Count & \\
& \\
\hline
\end{tabular}

\section{Design Validation}

Design validation is carried out by experts or experts using the assessment instrument sheet. In this study, there are two experts or experts, namely experts or teaching materials experts and material experts. Experts or teaching material experts are intended to validate products which include validation of content or content and validation of presentation. Meanwhile, material experts or experts are intended to validate products which include validation of material substance and validation of learning designs.

Teaching materials are said to be valid if according to the validator each component in the product is categorized as valid or very valid. The product validation by experts is as follows:

\section{Media Expert}

The questionnaire was addressed to teaching material experts, in this case a lecturer at the Islamic Institute of Religion Ma'arif (IAIM NU) Metro, who has Early Childhood Education qualifications, so that the results of the media that will be 
Fingerboard Media Development Calculate for the Cognitive Improvement of Teachers at RA Muslimat NU 1 Tulus Rejo

developed are in accordance with what researchers expect and can be used by children. early age.

The teaching material expert is M. Saidun Anwar, M.Pd. The following is the validation results from media experts:

Tabel 1.2

Product Validation From Media Experts

\begin{tabular}{|c|c|c|c|}
\hline No & Indikator & Skor & Ket. \\
\hline 1. & Media size according to children's needs & 4 & $100 \%$ \\
\hline 2. & The color used appeals to students & 4 & \\
\hline 3. & Accuracy of media with themes & 4 & \\
\hline 4. & $\begin{array}{l}\text { Images according to early childhood } \\
\text { cognitive development }\end{array}$ & 4 & \\
\hline 5. & $\begin{array}{l}\text { Size of the image used according to the } \\
\text { needs }\end{array}$ & 4 & \\
\hline 6. & $\begin{array}{l}\text { Suitability of images with cognitive } \\
\text { materials }\end{array}$ & 4 & \\
\hline 7. & $\begin{array}{l}\text { This counting fingerboard media provides } \\
\text { learning for early childhood cognitive } \\
\text { development }\end{array}$ & 4 & \\
\hline 8. & $\begin{array}{l}\text { Delivery on the counting finger board in } \\
\text { accordance with early childhood cognitive } \\
\text { development }\end{array}$ & 4 & \\
\hline \multicolumn{2}{|c|}{ Amount } & 32 & \\
\hline \multicolumn{2}{|c|}{ Average } & 4 & \\
\hline
\end{tabular}

Based on the above information, it can be known the percentage of experts teaching materials by $100 \%$, therefore the feasibility of the media of the counting fingerboard can be said to be very feasible.

\section{Material experts}

The questionnaire was addressed to material experts, in this case a lecturer at the Islamic Institute of Religion Ma'arif (IAIM NU) Metro, who has Early Childhood Education qualifications, so that the material in the media will be developed according to what researchers expect and have an impact on improvement. child's abilities. The material expert is Leli Fertiliana Dea, M.Pd. The following are the validation results from material experts: 
Tabel 1.3

Product Validation from Material Experts

\begin{tabular}{|c|c|c|c|}
\hline No & Indikator & Skor & Ket. \\
\hline 1. & $\begin{array}{l}\text { This counting fingerboard media provides } \\
\text { learning for the cognitive development of } \\
\text { children aged } 4-5 \text { years }\end{array}$ & 4 & $100 \%$ \\
\hline 2. & $\begin{array}{l}\text { The media content of the counting finger } \\
\text { board is well presented and clearly }\end{array}$ & 4 & \\
\hline 3. & $\begin{array}{l}\text { The contents of the calculated fingerboard } \\
\text { media are easy to understand }\end{array}$ & 4 & \\
\hline 4. & The suitability of numbers with media & 4 & \\
\hline 5. & Place the numbers according to the media & 4 & \\
\hline 6. & The color of the image appeals to learners & 4 & \\
\hline \multicolumn{2}{|c|}{ Amount } & 24 & \\
\hline \multicolumn{2}{|c|}{ Average } & 4 & \\
\hline
\end{tabular}

Based on the information above, it can be seen that the percentage of material experts is $100 \%$, therefore the appropriateness of the counting finger pad media can be said to be very feasible.

Based on the validation of the media experts and material experts mentioned above, it can be explained that the counting finger board media is very suitable to be used for the learning process, especially in developing early childhood cognitive abilities. In the following, the researcher presents a validation diagram for media experts and material experts about counting finger pad media:

\section{Diagram 1.1}




\section{Compute Fingerboard Media Validation}

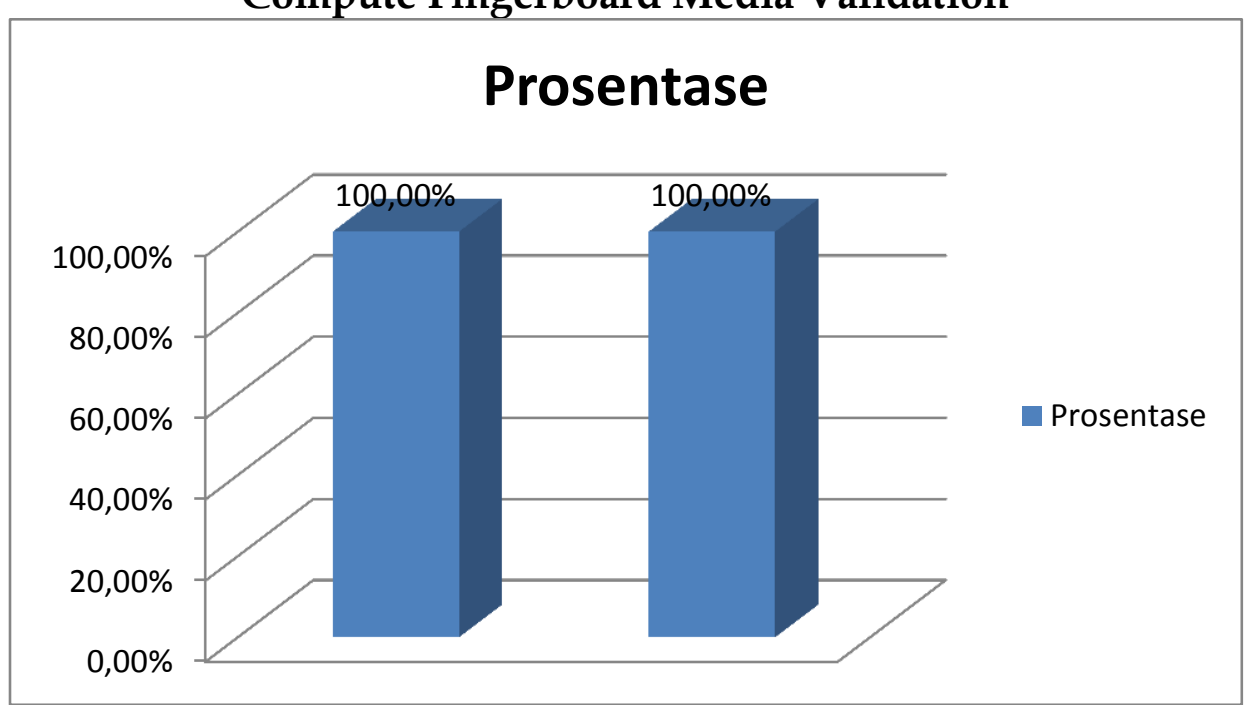

\section{Design Improvements}

The revision results can be explained as follows: The revision results from media experts are in the form of improvements and suggestions on the arithmetic finger board media This is the need for the use of more diverse colors to make it more attractive and the layout of the counting keyboard media must be improved to make it look attractive.

\section{Media Expert}

The revision results from material experts in the form of improvements and suggestions on the counting finger pad media, namely the need for an explanation of the image in accordance with the image placed on the top of the counting finger pad media.

\section{Material Expert}

Based on the two revisions from teaching materials experts and material experts in the form of improvements and suggestions related to counting finger pad media, the researchers have improved according to expert suggestions as follows:

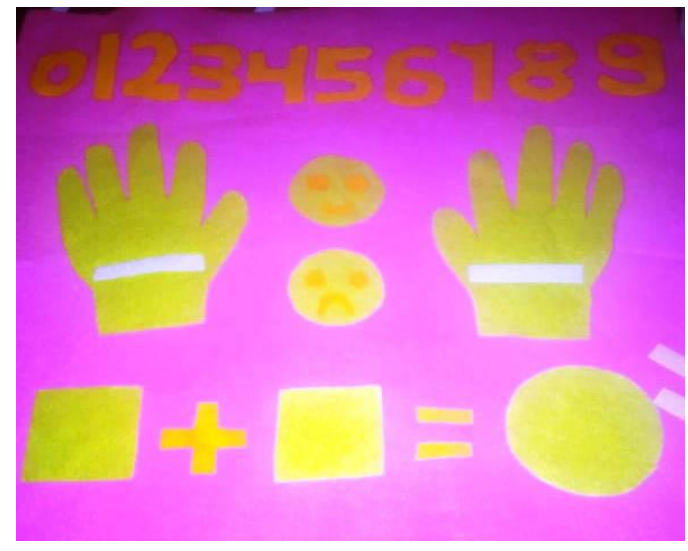

Figure 1.1

Calculated Fingerboard Media before Repair 


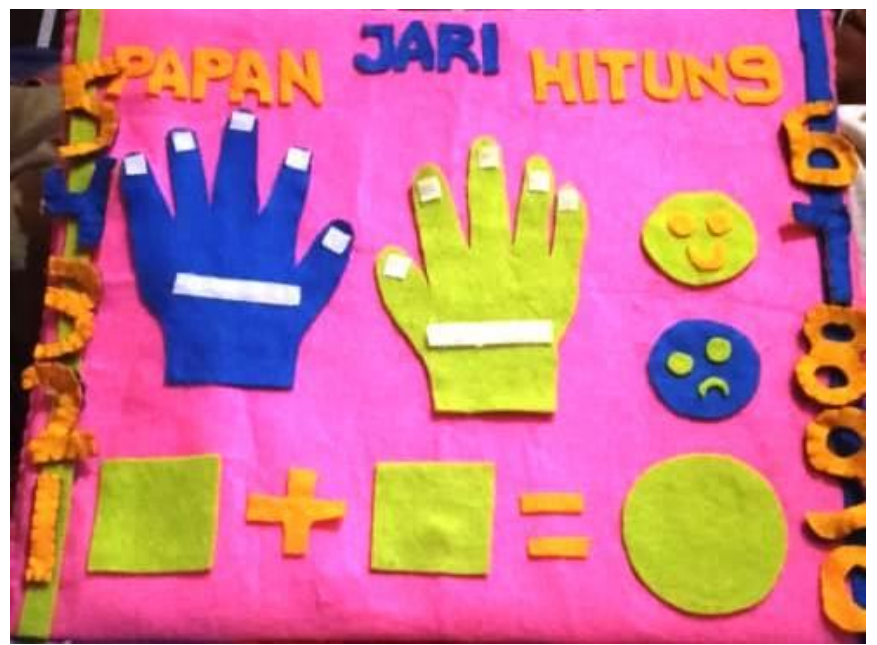

Figure 1.2

Calculated Fingerboard Media After Repair

\section{Product Trials}

There are two objectives of the trial, namely to determine the success or failure of the product to achieve the goal; and collect information for product improvement. Product trials are carried out after the teaching materials developed have been revised and declared valid by experts. Then then implemented in students. In this study, the subjects of the trial were children aged 4-5 years RA Muslimat NU 1 Tulus Rejo.

Before conducting a product trial, the researcher will compare the cognitive ability of symbolic thinking in children aged 4-5 years at RA Muslimat NU 1 Tulus Rejo before using counting finger pad media with the cognitive ability of symbolic thinking after children aged 4-5 years using counting finger pad media.

The following is the cognitive ability to think symbolically of children aged 4-5 years at RA Muslimat NU 1 Tulus Rejo based on the pre-survey data that the researchers conducted, namely:

Based on the table above, it can be understood that the cognitive abilities of children aged 4-5 years before using finger boards The count can be said that there are 1 child developing according to expectations, 8 children who are starting to develop and even 11 children who have not developed, and no one child who develops very well. Therefore, the cognitive abilities of children aged 4-5 years at RA Muslimat NU 1 Tulus Rejo before using counting finger board media can be said to have not developed.

Then the researchers conducted research and development on counting finger pad media in early childhood at RA Muslimat NU 1 Tulus Rejo with the aim of improving the abilities of early childhood.

Counting finger board media or flannel board media is a flat board media covered by a flannel cloth on which pieces of letters, numbers, pictures and symbols can be placed to facilitate the learning process. This counting finger board media is generally used in low-grade Kindergarten or Elementary School learning.

Counting finger pad media is often used in initial learning such as number recognition and addition concepts. 
Fingerboard Media Development Calculate for the Cognitive Improvement of Teachers at RA Muslimat NU 1 Tulus Rejo

The following is the cognitive ability to think symbolically for children aged 4-5 years at RA Muslimat NU 1 Tulus Rejo after using counting finger boards, namely:

Tabel 1.4

Hasil Penelitian Kemampuan Kognitif Anak Usia 4-5 Tahun Di RA Muslimat NU 1 Pekalongan

\begin{tabular}{|c|l|c|c|c|c|c|}
\hline \multirow{2}{*}{$\begin{array}{c}\text { No } \\
\text { Nama }\end{array}$} & \multicolumn{4}{|c|}{ Indikator } & \multirow{2}{*}{ Ket. } \\
\cline { 3 - 6 } 1. & Aditia Pratama & 1 & 2 & 3 & 4 & \\
\hline 2. & Aska Ramadhan & BSH & MB & MB & BSH & MB \\
\hline 3. & Alif Fatulmuin & BSB & MB & BSH & BSH & BSH \\
\hline 4. & Alif Musyafa & BSH & MB & BSH & MB & MB \\
\hline 5. & Safa Safinatun Najah & BSH & MB & BSH & BSH & BSH \\
\hline 6. & Muhamad Rizal Ariri & BSB & MB & BSH & MB & BSH \\
\hline 7. & Arina Zulfa Fitriani & BSH & MB & MB & BSH & MB \\
\hline 8. & Anisa Ramadhani & BSH & MB & MB & BSH & MB \\
\hline 9. & M. Afrizal Gonzales & BSH & MB & BSH & BSH & BSH \\
\hline 10. & Akbar Shaka Shahidan & BSH & MB & MB & BSH & MB \\
\hline 11. & Muhamad Akmal Zainurohim & BSH & MB & BSH & BSH & BSH \\
\hline 12. & Muhamad Gibran & BSB & BSB & BSH & BSB & BSB \\
\hline 13. & Rohib Noufal & BSH & MB & MB & BSH & MB \\
\hline 14. & Alan Adinata & BSH & MB & MB & BSH & MB \\
\hline 15. & Diyah Ayu Ramadhani & BSB & MB & BSH & BSH & BSH \\
\hline 16. & Deli Fitria & BSH & MB & BSH & MB & MB \\
\hline 17. & Alya Nur Oktaviani & BSH & MB & MB & BSH & MB \\
\hline 18. & Muhamad Nizam & BSH & MB & BSH & BSH & BSH \\
\hline 19. & Mahmud Rifa'i & BSH & MB & MB & BSH & MB \\
\hline 20. & M. Ibnu Alwi Fauzi & BSH & MB & BSH & BSH & BSH \\
\hline
\end{tabular}

Source: Documentation of RA Muslimat NU 1 Tulus Rejo Kec. Pekalongan Kab. East Lampung Year 2020

Note

$\begin{array}{lll}\text { BB } & : & \text { Not Yet Developing } \\ \text { MB } & : & \text { Starting to Develop } \\ \text { BSH } & : & \text { Developing according to Expectations } \\ \text { BSB }: & \text { Developing Very Well }\end{array}$

Indicators:

1) Count multiple objects one to ten

2) Get to know the concept of numbers

3) Recognizing the symbol number

4) Recognize letter symbols

Based on the table above, it can be understood that the cognitive abilities of children aged 4-5 years after using the counting finger board media can be said that there are 1 children who are developing very well, 8 children are developing as expected, 11 children are starting to develop. and even there are no children who are 
categorized as underdeveloped. Therefore, the cognitive abilities of children aged 4-5 years at RA Muslimat NU 1 Tulus Rejo after using counting finger board media can be said to have begun to develop.

\section{Product Revision}

The revised product will produce appropriate teaching materials so that it can be used in improving the cognitive intelligence of children aged 4-5 years at RA Muslimat NU 1 Tulus Rejo Kec. Pekalongan.

Tabel 1.5

\section{Calculated FingerBoard Media Products}

\begin{tabular}{|c|c|c|}
\hline Produk & Gambar \\
\hline $\begin{array}{c}\text { Calculated Finger } \\
\text { Board Media } \\
\text { Products }\end{array}$ &
\end{tabular}

$R \mathcal{E} D$ is a term used to describe activities related to the creation or invention of new, methods, products or services, and using new-found knowledge to meet market needs or demands. Techniques involving science, technology and mathematics are used in research and development.

As for this study, the development of arithmetic fingerboard media products. Counting finger board media or flannel board media is a flat board media covered by a flannel cloth on which pieces of letters, numbers, pictures and symbols can be placed to facilitate the learning process. This counting finger board media is generally used in low-grade Kindergarten or Elementary School learning. Counting finger pad media is often used in initial learning such as number recognition and addition concepts.

In the following, the researcher describes the RPPH using counting finger boards for children aged 4-5 years at RA Muslimat NU 1 Tulus Rejo, Kec. Pekalongan are as follows:

1. The Theme

This research was conducted on Tuesday, 27 October 2020 at RA Muslimat NU 1

Tulus Rejo Kec. Pekalongan with the theme "addition"

2. Materi

The material in this study are:

a. Numbers of objects one to ten

b. Get to know the concept of numbers

c. Know the symbol of number

d. Recognizing the letter

3. Opening (15 minutes) 

a. Line, flag ceremony
b. Walk forward in a straight line while carrying a book on your head and want to help a friend whose book has fallen
c. Share stories about the kinds of farm animals
d. Listening to the stories of the sholih / sholihah people
e. Always give thanks for the gifts given by God

4. Core (45 minutes)
a. Determine the theme according to the counting finger pad media
b. Adjusting the position of the counting finger board so that it can be seen clearly by students
c. Explain the learning activities using the counting finger board media that has been prepared
d. Fold a few counting fingers on one board, leaving a few fingers
e. After the child knows the concept of counting finger boards, the two finger boards can be used in learning

5. Rest (15 minutes)
a. Wash hands
b. Eat and drink
c. Play

6. Closing (15 minutes)
a. Asking about feelings during the day
b. Discuss what activities have been played today, what toys are the most popular
c. Assigning tasks to children to do at home, namely asking their parents about the law of raising dogs
d. Informing activities for tomorrow
e. Pray, greetings.

The steps for applying counting finger pad media to children aged 4-5 years at RA Muslimat NU 1 Tulus Rejo Kec. Pekalongan are as follows:

1. Determine the theme according to the arithmetic finger pad media.

Based on the research results, the researcher before starting the learning and development of the arithmetic finger pad product, the researcher must determine the theme that will be implemented into the counting finger pad media. In this study, the researcher has determined the theme of addition, as shown in the following figure:

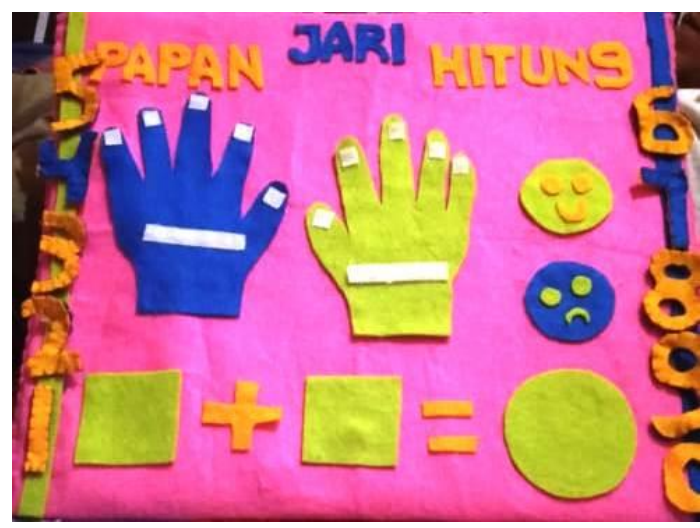

Figure 1.3

Calculated Fingerboard Media Summing Theme 
Based on the picture above, it can be concluded that the researcher has determined what is appropriate with the counting finger board media.

2. Adjusting the position of the counting finger board so that it can be seen clearly by students

Based on the results of the study, the researcher adjusted the position between the counting finger board media and the sitting position of the students, so that students were not obstructed from one another, so that all students could follow the learning with good and true, according to the following image:

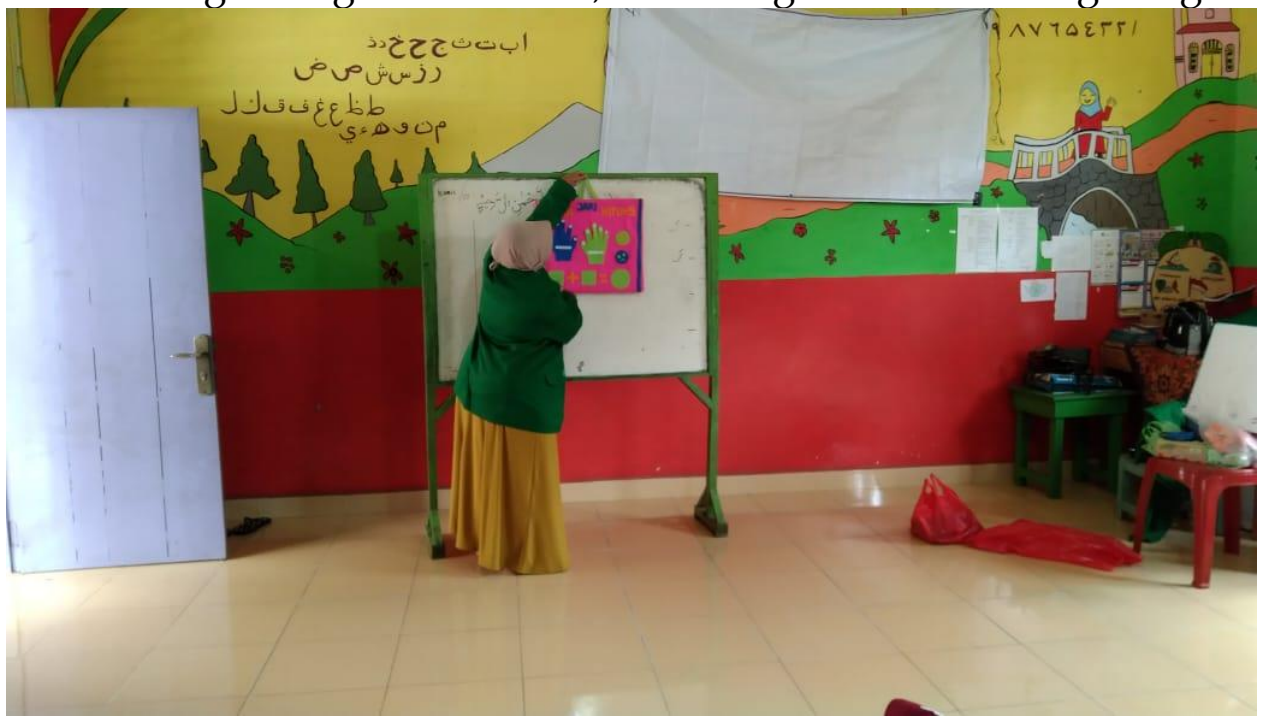

Figure 1.4

Setting the Position of the Calculated Finger Board Media

Based on the picture above, it can be concluded that the researcher has adjusted the sitting position of the students, so that students are not blocked from one another, so that all children can see the explanation.

3. Explain learning activities using counting finger pad media that have been prepared

Based on the research, the researcher explains learning activities using counting finger pad media to students, so that students understand how to use the counting finger pad media, according to the following picture:

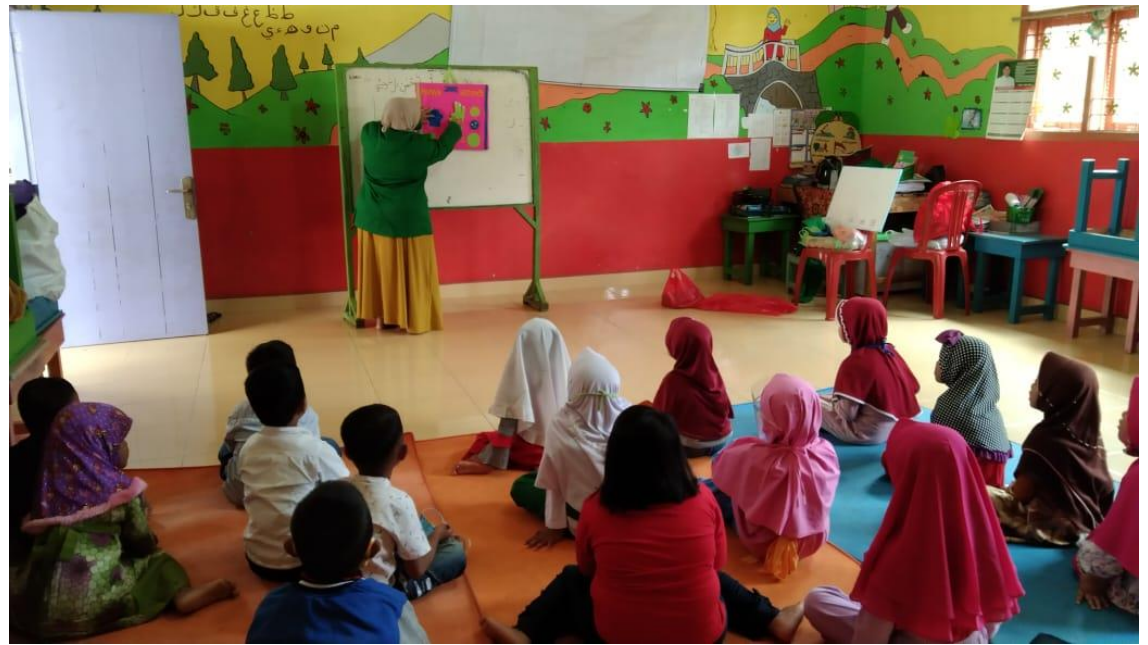

Figure 1.5 
Fingerboard Media Development Calculate for the Cognitive Improvement of Teachers at RA Muslimat NU 1 Tulus Rejo

\section{Explaining Learning Activities}

Based on the picture above, it can be concluded that the researcher has provided an explanation of how to use counting finger pad media to children.

4. Fold a few counting fingers on one board, leaving a few fingers.

Based on the results of the study, students were asked to use the counting finger pad media according to the direction of the researcher, as shown in the following picture:

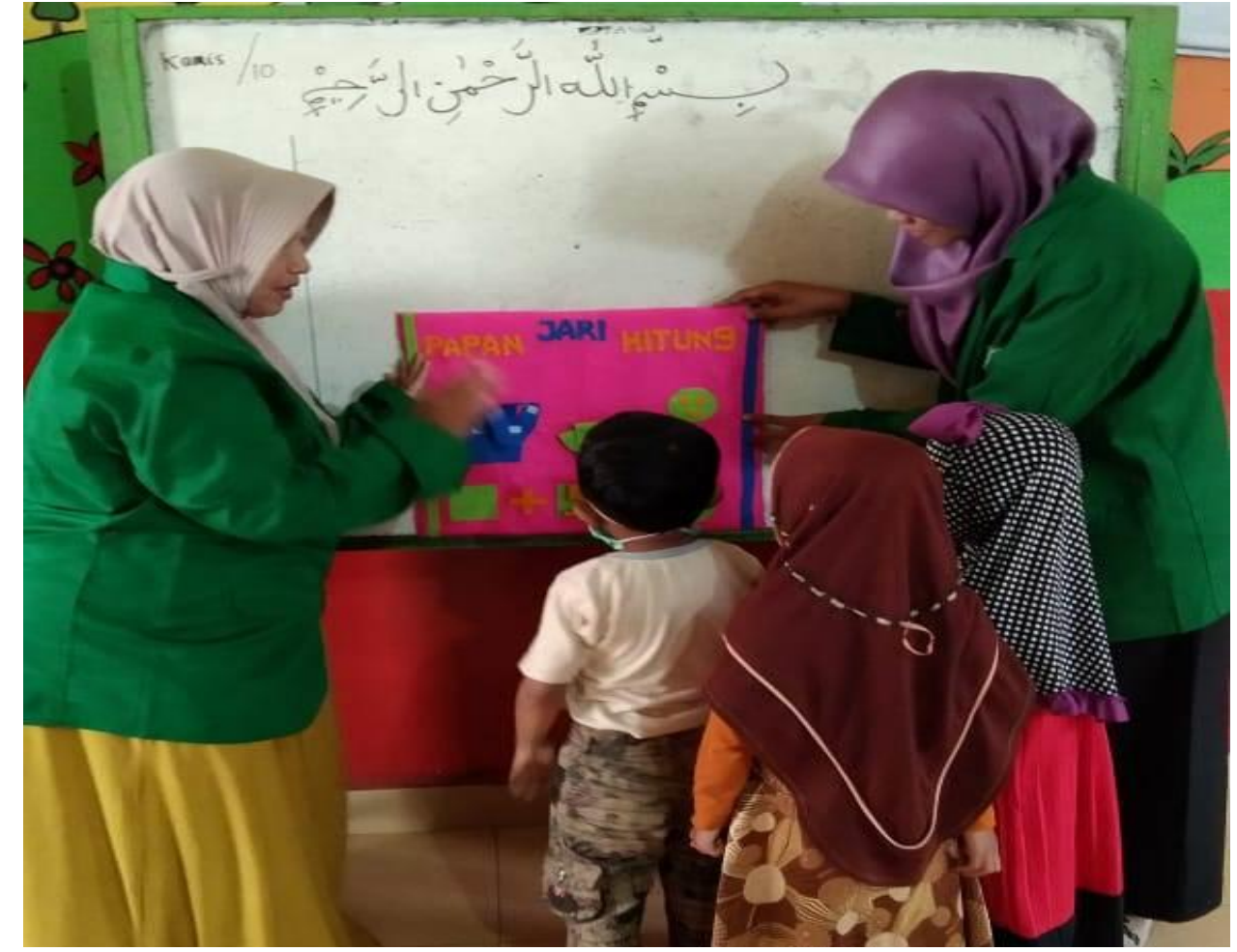

Gambar 1.6

Anak diminta mencoba Media Papan Jari Hitung

Based on the picture above, it can be concluded that the researcher has given an example and has asked the child to try to use the counting finger pad.

5. After the child knows the concept of counting finger boards, the two finger boards can be used in learning.

Based on the results of the study, if the students already know about how to use the media boards finger count, the students were given the opportunity to use the boards finger count, as the following figure: 


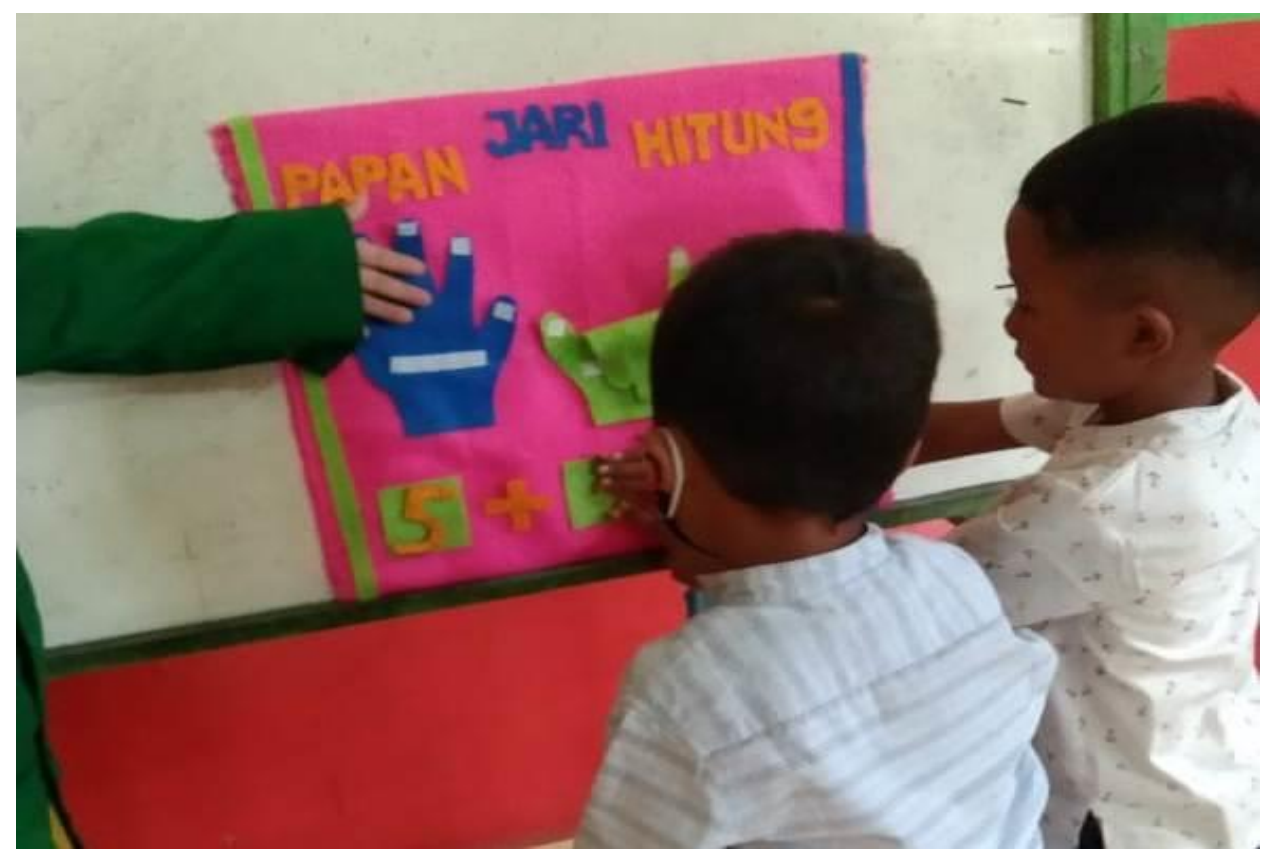

Gambar 1.7

Anak menggunakan Media Papan Jari Hitung

Based on the picture above, it appears the child is able to use the media board finger count in accordance with the explanation which has been given.

\section{CONCLUSION}

The most important finding of the article is that the development of arithmetic finger pad media is able to stimulate children in playing and learning activities. However, this article has not touched the area of all aspects of development as a result of the use of counting board media. This article on the development of counting finger pad media is an effort to stimulate children's cognitive development.

\section{ACKNOWLEDGEMENT}

Thank you to all the leadership and teacher council of RA 1 Muslimat Tulus Rejo East Lampung because we were allowed to be able to carry out the research. Moreover, thanks also to the Maarif NU Islamic Institute, especially the lecturers and reviewers for their input and suggestions so that we can complete this article. furthermore thanks also to the manager of the journal JCD: Journal Of Childhood Development for being willing to accept and publish the articles we researched.

\section{REFERENCES}

Fauziddin, M. (2018). Useful of Clap Hand Games for Optimalize Cogtivite Aspects in Early Childhood Education". Jurnal Obsesi: Jurnal Pendidikan Anak Usia Dini, 2(2).

Gall, M. D. G. J. P. \& B. (2003). Educational Research An Introduction. Pearson Education Inc.

M. Yusuf, Ani Susilawati, A. P. M. (2019). Indonesian Journal of Islamic Education Studies (IJIES) Online: https://ejournal.iai-tribakti.ac.id/index.php/ijies. 2(2), 28-39.

Mahnun, N. (2012). Media Pembelajaran (Kajian terhadap Langkah-langkah Pemilihan Media dan Implementasinya dalam Pembelajaran). Jurnal Pemikiran Islam, 37. 
Fingerboard Media Development Calculate for the Cognitive Improvement of Teachers at RA Muslimat NU 1 Tulus Rejo

RI, D. A. (2009). Al-Qur'an dan Terjemahnya. PT. Rilis Grafika.

Rizky, N. A. F. (2017). Meningkatkan Kemampuan Berhitung Permulaan (1-10) Melalui Media Papan Flanel pada Anak Kelompok A di TK PKK 106 Merten Sanden Bantul. Jurnal Pendidikan Anak Usia Dini.

Rohani. (2016). Mengoptimalakan Perkembangan Kognitif Melalui Kegiatan Bermain. RAUDHAH, IV(2).

Suharmanto. (2014). Pengembangan Media Pembelajaran Papan Hitung Pembagian Pada Mata Pelajaran Matematika Sekolah Dasar Kelas 2. Jurnal Teknologi Pendidikan. 